\title{
Obstacles and Opportunities for Financing the Fight against Covid-19 in the Debt Trapped Zimbabwe
}

\section{Gorden Moyo}

Faculty of Social Sciences and Humanities, Lupane State University, The Public Policy and Research Institute of Zimbabwe (PPRIZ), Bulawayo, Zimbabwe

Email: gordenmoyo@gmail.com

How to cite this paper: Moyo, G. (2020) Obstacles and Opportunities for Financing the Fight against Covid-19 in the Debt Trapped Zimbabwe. iBusiness, 12, 52-68. https://doi.org/10.4236/ib.2020.122004

Received: May 26, 2020

Accepted: June 20, 2020

Published: June 23, 2020

Copyright (c) 2020 by author(s) and Scientific Research Publishing Inc. This work is licensed under the Creative Commons Attribution International License (CC BY 4.0).

http://creativecommons.org/licenses/by/4.0/

\section{(c) (i) Open Access}

\begin{abstract}
The coronavirus aka Covid-19 pandemic arrived in Zimbabwe at a time when the country was in the throes of its worst economic turmoil in recent years. Within months of its arrival, the pandemic has already upended the public healthcare system, eroded the livelihoods of millions of people, and further deepened the economic headwinds in the country. Apparently, Zimbabwe has been in a crisis mode since the beginning of the $21^{\text {st }}$ Century. As such, the pandemic has added an extra burden to the country that is already creaking under mounting weight of external debt peonage, fiscal deficit, liquidity crisis, and international isolation among many other social and economic ills. In this context, the country faces an uphill task in mobilising financial and non-financial resources in order to contain the coronavirus crisis. This article therefore sets out to examine the obstacles and opportunities for financing the fight against Covid-19 pandemic within a discursive context of a debt trapped Southern African country.
\end{abstract}

\section{Keywords}

Covid-19, Debt Relief, Domestic Resource Mobilisation, Financing Gap, Public Finance Management, Special Drawing Rights, Zimbabwe

\section{Introduction}

The coronavirus aka Covid-19 pandemic landed in Zimbabwe at a time when the country was in the throes of its worst economic turmoil in recent years. The pandemic has already upended the public healthcare system, eroded the livelihoods of millions of people, and further deepened the economic headwinds in the country. It is common cause that Zimbabwe has been in a crisis mode since 
the beginning of the $21^{\text {st }}$ Century. Currently, the country is faced with a huge external debt, fiscal deficit, and almost half of the population is food insecure.

In this context, the country faces huge challenges in raising enough internal resources to contain the Covid-19 pandemic. The challenges are further compounded by the fact that Zimbabwe has been defaulting on its debt obligations hence unable to access concessionary loans from the international financial institutions. This article therefore sets out to examine the obstacles and opportunities for financing the fight against Covid-19 pandemic within a discursive context of a debt trapped Southern African country.

There is no debate that Covid-19 is a threat to public health care, to the livelihoods of millions of people and to the national economies across the globe. As at 4 June 2020, Zimbabwe has recorded 222 confirmed cases of coronavirus infections, 4 deaths, and 29 recoveries (The Chronicle News Paper, 2020). While these figures are low, it remains unclear whether these reflect reality or a lack of robust testing. What cannot be doubted however is that urgent funding is required to combat the spread of the virus as well as cushion the poor and vulnerable communities from the already visible effects of the pandemic. Additional resources are needed to support the critical sectors of the economy that have been ravaged by economic inactivity due to the coronavirus crisis.

The research information was drawn from key informant interviews drawn from the Reserve Bank of Zimbabwe, Ministry of Finance, Ministry of Health, and Office of the Provincial Governor of Bulawayo, academia, media, and civil society. The consulted individuals have intimate knowledge of the efforts towards combating the coronavirus and the debt situation in Zimbabwe. To respect the anonymity of these individuals, the interviews were held off record. Secondary data obtained from the web-based sources were also extensively deployed in this work. The article is structured as follows: Section 2 provides a brief socio-economic and political context, section 3 examines the financing gaps; sections 4 presents the international response to Covid-19, sections 5, 6, and 7 discuss debt relief, emergency funding, and domestic resource mobilisation respectively; section 8 discusses the public finance management while section 9 concludes the discussion.

\section{Socio-Economic and Political Context}

It is the argument of this article that Zimbabwe's financing woes that are hampering the fight against the coronavirus are retraceable to the country's international isolation under the former President Robert Mugabe who was ousted by the military in November 2017. Sadly, the successor government of Emmerson Mnangagwa has failed to normalise its relations with the rest of the international community in order for the country to enjoy its full rights as a member of the international comity of nations (Moyo, 2020). This is because the cases of human rights violations, abduction of political opponents, electoral smithing, illicit financial flows, and corruption among others have not been discontinued de- 
spite the fact that the Mnangagwa administration touts itself as "a listening government", "a new dispensation", "a Second Republic", and "Zimbabwe is Open for Business".

It is therefore hardly surprising that the country remains in the peripheries of the global financial systems as will be explained anon. With respect to the coronavirus pandemic, it will be noted that the arrival of the pathogens in Zimbabwe coincided with the country's worst economic turmoil ever. In particular, the virus landed on the back of Cyclone Idai which left 270,000 people homeless in 2019, devastating drought which has seen 8.5 million people being food insecure in a population of 16 million, and sovereign debt burden of over US $\$ 20$ billion (Moyo, 2020; Ncube, 2020; ZIMCODD, 2020). In this context, the country has been running on a fiscal deficit driven by government's excessive spending including subsidies for supporting small scale farmers, government grain procurement at above market prices, urban public transport, and garrison shops for the security services.

At the same time, the country's external debt is high and largely in arrears, cutting off the country from access to loans mainly from the multilateral and bilateral creditors. Available statistics from the Reserve Bank of Zimbabwe indicate that the public debt stock is unsustainable with domestic debt growing by an alarming 2789 percent between 2013 and 2019 from US $\$ 0.36$ billion to US $\$ 10.4$ billion respectively (World Bank, 2020). Similarly, external debt has also grown by 27 percent over the same period from US $\$ 10.22$ billion to US $\$ 13.13$ billion (ZIMCODD, 2020).

As such, the country remains incapable of accessing resources from the international financial institutions (IFIs) such as the World Bank and the International Monetary Fund (IMF) because of its continued failure to service its debts to these institutions. Zimbabwe's dire situation was captured by the Finance Minister Mthuli Ncube in a leaked letter to the IMF on 2 April 2020. In this five-page letter, the Finance Minister begged the IMF to bail out the debt entrapped government in order for it to be able to respond to Covid-19 pandemic (Ncube, 2020). Zimbabwe's desperate situation was palpable in the tenor of the letter.

Over and above the problem of external debt overhang, Zimbabwe's financial woes are also aggravated by blatant corruption and illicit financial flows. Over the past two decades, the country has lost more than US $\$ 25$ billion through illicit financial flows including externalisation and money laundering (Choruma, 2018; Dlamini and Mbira, 2017). In his 2020 budgetary statement, the Minister of Finance decried the level of corruption in the country noting that it causes economic malaise, wastage of public resources, jeopardises the environment for domestic and foreign investment and general morale in the public service (Government of Zimbabwe, 2019). It is obvious that such illicit financial flows have reduced the levels of resources available to the country to finance its development objectives including preparations for national disasters such as the coronavirus. 
As a result, the healthcare system in Zimbabwe today is vulnerable and lacks the required basic medical equipment let alone testing kits, ventilators, intensive care units, personal protective equipment, sanitizers, and face mask to combat the spread of the Covid-19 pandemic. Moreover, a large portion of the population in the country lacks access to essential health services due to a shortage of health workers, particularly in rural and remote areas. And yet, the fight against the Covid-19 pandemic ultimately depends on doctors, nurses, technicians, and other health care personnel who treat and prevent infections.

However, notwithstanding the above obstacles, donor agencies, private individuals, business, faith communities, Non-Governmental Organisations (NGOs), Civil Society Organisations (CSOs), and philanthropists among others have been making some generous contributions towards the fight against the coronavirus. Even the World Bank has approved a sum of US\$7 million as a grant towards Covid-19 mitigation (Reuters, 2020). The donations, grants and contribution have for the time being enable government to respond to the urgent needs of the frontline health professionals (for more nuanced discussion on contributions see the section on emergency funding in this article below). However, while appreciating these contributions, it should be noted that Zimbabwe has huge financing gaps that will require the policy makers to urgently plug if the country is to limit if not defeat the coronavirus pandemic.

\section{Funding Gaps}

There is no doubt that in order to fight against Covid-19 Zimbabwe will need both financial and non-financial resources. Specifically, the country requires massive liquidity and financing support to deal with the immediate fall-out from the pandemic and its economic repercussions. According to the estimates provided by the government, the country will require US $\$ 2.2$ billion in order to effectively contain the pandemic (ZIMCODD, 2020). As the experiences of countries such as China, the UK, the U.S., and the EU have all shown, even the well resourced countries are struggling to manage the outbreak of the Covid-19 pandemic. Clearly, without the same capacities and capabilities Zimbabwe faces a Herculean task. This includes providing more hospitals, more hospital beds, more medical staff, more medical supplies, and personal protective equipment among others.

As part of the intervention measures to combat the pandemic and to shore up the ailing economy, on 27 March 2020, the government of Zimbabwe declared Covid-19 crisis a National Disaster a move allowing it to commandeer state resources towards fighting the pandemic. At the same time, the Minister of Health also enacted Statutory Instrument 77/2020 to spell out the measures for prevention, containment, and treatment of the pandemic (ZIMCODD, 2020).

Simultaneously, government launched a US\$2.2 billion domestic and international humanitarian appeal covering the period April 2020 to April 2021 (ZIMCODD, 2020). In addition, on 30 April 2020, President Mnangagwa an- 
nounced a Z $\$ 18$ billion (US $\$ 360$ million) Covid-19 Economic Recovery and Stimulus Package to cushion the private sector from the effects of the coronavirus crisis (New Zimbabwe Newspaper, 2020). Apparently, this is a huge package nearly 9 percent of GDP and 28.6 percent of the 2020 National Budget. Unfortunately, as intimated already, the country does not have that kind of money and government did not indicate where this whooping $\mathrm{Z} \$ 18$ billion stimulus package would come from. Some observers fear that the government will print money in order to fund this stimulus package (Moyo, 2020).

Apparently, the largest funding gap in Zimbabwe is visible in the public health care provisioning. The health workers, the medical staff, and other responders on the frontline of containing Covid-19 do not have adequate test kits, ventilators, masks, personal protective equipment, and sanitizers among the other urgent needs. Currently, there are two equipped hospitals that have been designated as isolation centers namely; Wilkins Infectious Diseases Hospital in Harare and Thorngrove Infectious Diseases Hospital in Bulawayo (Moyo, 2020). The rest of the designated centers across the provinces and districts are isolation centers by name. The other areas falling short of necessary funds are the water, hygiene, and sanitation sectors, which focus on providing clean water for hand washing. For example, the city of Bulawayo has perennial waters problems with some suburbs experiencing 48 hours of water rationing.

On the other hand, the lockdown measures taken by government to arrest the spread of pathogens such as social distancing; suspending gatherings of more than 50 people; suspending prayers at churches and mosques, closing of all schools, colleges, universities, and businesses have led to some unintended social and economic consequences. For example, millions of people's livelihoods have been disrupted with disproportionate impact on poor households, and microsmall-medium-enterprises as well as the informal sector in general (ZIMCODD, 2020; Mckensey \& Co., 2020; Chidaushe, 2020; Siwisa, 2020).

Since over 80 percent of Zimbabweans are in the informal sector, lockdowns have essentially ravaged the livelihoods of the poor and the vulnerable communities right across the country hence a number of informal traders, hawkers, and street vendors are finding it difficult to obey the lockdown regulations. At the same time, the closure of international border has seen the country's foreign currency earnings drop as a result of the slump in mineral exports, travel, tourism revenues, and diaspora remittances (also see the ZIMCODD, 2020; Mckensey \& Co., 2020; Chidaushe, 2020; Siwisa, 2020). Consequently, government has witnessed massive reductions in revenues which are desperately required for containing the Covid-19 pandemic.

In net, Zimbabwe requires huge financial and non-financial resources including the resources to support public awareness; fortify the public health facilities; contain the spread of the virus; infection detection through enhanced testing capacities; and establish the capacity of the country to respond to the economic and welfare challenges emerging from the lockdown measures. And yet, by its own admission, the government of Zimbabwe has no capacity to fund these es- 
sential services and processes (Ncube, 2020). It is therefore the object of the next section to unpack some of the challenges that the country faces in its bid to raise the resources for containing the coronavirus pandemic.

\section{International Response}

It will be recalled here that when the Covid-19 erupted onto the global stage, the IMF, and the World Bank Group as well as the G20 (an international forum consisting of 20 emerging and rich countries namely Argentina, Australia, Brazil, Canada, China, European Union, France, Germany, India, Indonesia, Italy, Japan, Mexico, Russia, Saudi Arabia, South Africa, South Korea, Turkey, UK, and the U.S.) offered various financing facilities to the poor and economically vulnerable countries to contain the ravages of the pandemic. In particular, three financing windows, that is, the IMF debt relief initiative, the G20 repayment standstill, and the IMF and World Bank concessionary loans have been offered to the poor and economically vulnerable countries.

Thus, on 13 April 2020 the IMF approved debt service relief for 25 poorest countries including Malawi, Mozambique, and Rwanda under the IMF's revamped Catastrophe Containment and Relief Trust (CCRT) as part of its response to the global pandemic (IMF, 2020; Global Justice, 2020). While the provision of debt relief by IMF is a step in the right direction to support the poor countries, Zimbabwe is not eligible to benefit from this financing facility all because of a technical condition that does not permit a defaulting debtor to benefit from either of the Bretton Woods Institutions or any of the regional multilateral development banks. The fact that Zimbabwe is in arrears with the World Bank, African Development Bank, and the European Investment Bank excludes the country from accessing these resources to contain the coronavirus crisis.

Likewise, the country is not on the list of the countries that have been earmarked to benefit from the concessionary loans offered by the Bretton Woods Institutions. While other countries with outstanding debts may qualify for the bailout, Zimbabwe does not qualify because the government has previously reneged on servicing its debts to the World Bank, African Development Bank, and the European Investment Bank. Similarly, the country is excluded from debt standstill offered by the G20 for the same reason. In short, Zimbabwe's external debt overhang stands as a huge obstacle against the country's fight against the coronavirus crisis.

The other problem is that the current global response to the menaces of the coronavirus is in the form of loans instead of grants. Eurodad (2020) observes that the emergency financing provided in the form of loans, public debt will increase the debt of the beneficiaries by at least 14.2 percentage points of GDP. This simply means that the support offered by the Bretton Woods Institutions to deal with the impact of the Covid-19 is more of a paracetamol prescription which does not address the real ailment; instead, it just postpones the pain without a cure. Accordingly, even if Zimbabwe was eligible to access the resources from the international financial institutions, this would simply postpone 
the financing problem in the country rather than resolving it.

The other obstacle to Zimbabwe's resource mobilisation effort has been presented by the refusal by the U.S. and India to authorise the Special Drawing Rights (SDRs). The SDRs could possibly be one of the most viable, fast, easy, and debt-free mechanism for raising financial resources to raise hard currency for the cash strapped Zimbabwe (Gallagher, Ocampo, \& Vulz, 2020). To be clear, SDRs are a form of global money issued by the IMF to its Member States. They are held in the foreign reserves of Member States of the IMF and can be traded or used for transfers to other country's central bank. The IMF Managing Director, Kristalina Georgieva has expressed herself in favour of a fresh issue of SDRs. At the same time, many other luminaries including Joseph Stiglitz the former President of the World Bank and Gordon Brown-the former Prime Minister of Great Britain have both called for the issuance of SDRs to assist the poor and vulnerable countries to fight the coronavirus (also see Patnaik, 2020).

While Zimbabwe is a defaulting member of the multilateral institutions, it is entitled to its proportion of SDRs held by the IMF. To be clear, SDRs are offered without conditionalities and discrimination such as those that prevented Zimbabwe from benefiting from the IMF-Catastrophe and Relief Trust (CCRT). It would be remembered that at the height of the global financial crisis in 2009, IMF issued SDRs to the value of US $\$ 259$ billion to boost liquidity in the international system. And, despite the fact that Zimbabwe was a defaulter and was in huge arrears to its creditors, the IMF allocated 500 million SDRs to the then Government of National Unity (GNU) (Moyo, 2020).

However, despite the widespread backing for the additional allocation of SDRs, the U.S. which holds controlling shares of the IMF is reportedly the main holdout (ActionAid, 2020). The Trump-administration is concerned that SDRs will provide financial resources to some "rogue countries" such as Cuba, Iran, North Korea, and Venezuela who may use the funds to undermine global stability, peace and security rather than for Covid-19. The U.S. is also wary of China which it accuses of "mishandling" the origins of the coronavirus outbreak to the extent that the Trump-administration calls it the "Chinese virus" or the "Wuhanvirus" in reference to Wuhan, the city in Hubei province where the virus was first identified.

In this context, Zimbabwe's chances of accessing huge amounts of financial resources are glimmer except for alms from humanitarianists. It is, however, the argument of this article that given the interconnectedness of Africa's economies, the AU's defragmentation effort through the African Continental Free Trade Area (AfCFTA), global connectivity through the Chinese Belt and Road Initiative (BRI), and the globalised nature of Covid-19, omitting Zimbabwe and some of the vulnerable countries from the global financial assistance will leave the world badly exposed to the Covid-19 infections. This is because the coronavirus pandemic knows no boundaries, no race, no class, and no ideology. Arguably, no country is safe as long as the pandemic is allowed to fester in some poor coun- 
tries like Zimbabwe. The following section explores debt relief as an option that should be strongly campaigned for during this era of Covid-19.

\section{Debt Relief}

Some observers posit that Zimbabwe's external creditors should consider debt forgiveness for the debt entrapped country. This call resonates with Pope Francis' Urbi et Orbi address at Easter in which he called for the forgiveness of debts owed by poor nations so that they can combat the coronavirus pandemic (Toussaint, 2020; Onyekwena \& Ekeruche, 2020). The French President Emmanuel Macron has also added his voice by categorically calling for the cancellation of Africa's debt. Similarly, the African Ministers of Finance, the United Nations Economic Commission for Africa, and the United Nations Conference on Trade and Development have all called for debt moratoriums in Africa. This has been further reified by a legion of perennial campaigners for debt justice that includes ActionAid, African Network for Debt and Development, Southern African People's Solidarity Network, the Jubilee Debt Campaign, Eurodad, and Oxfam among others (Soren, 2005).

It is argued here that a holistic external debt cancellation for all of Zimbabwe's external debt payments, interests, charges, and penalties could enable the country to mitigate against Covid-19 crisis (also see, Adhikari, 2020; Jubilee Debt Campaign, 2020; Eurodad, 2020). It is not uncommon for countries that have been severely affected by sudden shocks such as natural disasters or outbreaks of diseases to call for debt cancellation. Haiti, for example, had the debts it owed to major creditors cancelled after the 2010 earthquake. In the same vein, the Mano River States namely; Liberia, Sierra Leone, and Guinea together with DRC called for debt cancellation when they were hit by the Ebola epidemic.

While Zimbabwe will not directly benefit from the cancellation because it has already been defaulting in its arrears, debt cancellation would give the country the breathing space and public confidence to better address the economic and social challenges of the Covid-19 outbreak without the handcuffs of debt overhang. Accordingly, debt cancellation should not be tied to any neoliberal policy conditionalities including austerity measures, privatisation, trade liberalisation, destatisation, deregulation, decontrol, hikes in interest rates, privatisation of parastatals and state enterprises, and cuts in public services such as health and education among others (Jubilee Debt Campaign, 2015; Moyo, 2020). This is because the country's need for relief and emergency finance is urgent and cannot wait for the protracted elaborate policy prescriptions which ironically contributed to the accumulation of the said debt in the first place.

Moreover, apart from multilateral creditors such as the World Bank, the African Development Bank, and the European Investment, and bilateral creditors such Paris Club, this article argues that non-Paris Club creditors especially China should also cancel Zimbabwe's debt. This is because China has become a prominent lender in the country. According to a Chinese diplomat in Harare, 
China has extended US $\$ 2.5$ billion to Zimbabwe in loans, investment and grants between 2010 and 2019 (Telesur, 2020). What is further unsettling is the claims that the Mnangagwa regime has signed US\$16 billion worth of investment deals since coming to power in November 2017 most of which were not approved by Parliament. Be that as it may, Beijing has made some contributions to the current fight against the coronavirus viewed by some critics as the Chinese "coronavirus diplomacy" meant as public relations stunt to cover up its resource imperialism in the country (see the section on emergency funding below).

As such, there are concerns that the government of Zimbabwe has been paying some of these Chinese debts using mineral resources thereby mortgaging the country to Beijing (Chigumira, Mupunga, and Chipumho, 2018). Wahoro Ndoho the Chief Executive Officer of Euclid Capital-Kenya has also raised a red flag by claiming that African countries will have no option but to offer assets including arable land to service their debts especially to China (Daily Nation News, 2020). As per the Wall Street Journal report, Zambia was considering giving China some mining assets as collateral in exchange for deferral or forgiveness of its sizeable debt (Daily Nation News, 2020). Viewed from this perspective, the proposed debt cancellation will free some resources-tied to debts thereby improving the investment climate for Zimbabwe.

As an "all-weather friend" of Zimbabwe, China's gesture of debt cancellation to Zimbabwe will enable the Euro-American bilateral creditors to do the same. At the moment these creditors are uncomfortable with cancelling debts because China and some vulture creditors may have a free ride on the beneficiaries. This is based on the fact that after 33 countries received debt relief through the Highly Indebted Poor Countries (HIPC) initiative and the Multilateral Debt Relief Initiative (MDRI) offered by multilateral and bilateral creditors in the $2000 \mathrm{~s}$, most of the African countries went on to contract more debts from China and commercial creditors ( also see Sun, 2020). This has raised frictions and suspicions in the debt-politics even though China also offered debt cancellation to some African countries in the 2000s (Moyo, 2009).

Viewed from this perspective, it is argued here that debt cancellation process needs to be coordinated by all the multilateral, bilateral, and commercial creditors in order to avoid free-riding by vulture creditors. In addition, key countries such as the China, UK, the U.S., and the EU countries should pass legislation to prevent debt vultures from benefiting from debt-cancellation that is earmarked for Covid-19 crisis.

\section{Emergency Funding}

Despite the obstacles outlined above, there still exists some opportunities for Zimbabwe to mobilise funding to contain the coronavirus. It is pleasing to note that contributions are already flowing towards the emergency fund set up by government. In his speech to the ruling party the Zimbabwe African National Union-Patriotic Front (ZANU PF) Politburo held on Wednesday 6 May 2020 in 
Harare, President Mnangagwa thanked various contributors to the fight against Covid-19 including the People's Republic of China, United Arab Emirates, India, Japan, the EU, the UK, the U.S., and the African Union (AU). Below is a snapshot of some of the donations that Zimbabwe has received:

- The EU: US $\$ 45.5$ million to Health Development Fund which is jointly managed by the UNICEF and the UNEFPA.

- US $\$ 25$ million from the Global Fund.

- US $\$ 5$ million from African Medallion Group.

- 100,000.00 Pounds donation of protective equipment to Wilkins Hospital from the Department for International Development (DFID, UK).

- US $\$ 470,000.00$ from the United States Agency for International Development (USAID).

- US $\$ 7$ million grant from the World Bank Group.

- 10,000 litres of hand sanitizers for hospitals nationally, knapsack sprayers and 15,000 tonnes of disinfectants and 40,000 litres of diesel from the Green Fuel Fossil ZimBitumen World.

- Ecosure, a subsidiary of Zimbabwe mobile phone operator Econet offered the following: Personal protective equipment for all doctors and nurses; free transport for nurses and doctors to commute to work and in sanitised vehicles.

- An upgrade worth US $\$ 5000,000.00$ to Harare's main Coivid-19 centre, the Wilkins Infectious Disease Hospital.

- A donation of 50,000 masks, and 510 protective suits by 2 Chinese firms to the First Lady Auxillia Mnangagwa's charity orgainsation.

- Equipment including 166,000 face masks, 7600 protective suits, 20,000 test kits, 12,000 pairs of gloves and five ventilators from the Chinese Embassy.

- 20,000 test kits, 100,000 face masks and 10,000 protective suits and face shield from China's richest man Jack Ma.

- US $\$ 3$ million donation from China International Development Cooperation Agency to UNICEF Zimbabwe (all figures were collected from the press reports by the author).

The list of donations and grants above are only indicative, a lot more has been contributed by various countries, companies, organisations, and individuals. However, while mobilising resources for combating the coronavirus is critical, it is equally important to pay attention at the country's ability to effectively deploy those resources. It is widely acknowledged that Zimbabwe's economy has been badly smitten by corruption, illicit financial flows, and mismanagement. For these reasons, it is disconcerting that there are still many hospitals and clinics across the country that have not benefited from the emergency funding yet all these and many other contributions have been made to the government.

This gives rise to legitimate suspicions of abuse/misuse of public resources in Zimbabwe. It would be foolhardy to expect that contributors to the Covid-19 Fund would continue providing donations without some assurances that their 
funds would not be lost to corruption or wasted in the context of weak institutions and poor governance. To this extent, government will therefore need to put in place strong measures in order to arrest the scourge of corruption which is blatant in the country (see the section on public finance management below).

\section{Domestic Resource Mobilisation}

The coronavirus crisis provides Zimbabwe with the best opportunity to rethink its domestic resource mobilisation strategies. This is because, even before the outbreak of the Covid-19 pandemic, the on-going global developments including, international migration, global financial crisis, and the rise of economic nationalism in the U.S. and some parts of Europe, external sources of financing have been slowly drying up. Moreso, in the current context of the coronavirus crisis where most countries are looking inward to save their own populations, the poor and vulnerable countries are only viewed as footnotes.

While these developments have affected most of the poor and economically vulnerable countries across the globe, Zimbabwe has been hard hit because of years of international isolation. Therefore the need to increasingly raise domestic resources rather than rely on more volatile external finance such as official development assistance should be privileged in Zimbabwe. A recent paper by the Zimbabwe Coalition on Debt and Developments (ZIMCODD) titled Zimbabwe COVID-19 Response Mechanism: The Resource Factor, presents a number of domestic measures which government should seriously consider in its effort to cushion the poor and vulnerable people as well as critical sectors of the economy. These are summarised below:

- Government should consider a temporary reduction in individual income tax which will leave the population with some additional disposable income to counter the negative effects of the Covid-19 pandemic. Faced with the need to self-isolate and limit movement, individuals and households are faced with the need to continuously stock groceries, medicines and other essentials, hence the need to lower income taxes.

- Government should consider deferring payment of corporate tax because the 49-day lockdown has resulted in a lot of companies having cash flow gridlocks and at times failing to honour their tax obligations. As such millions of jobs in both the formal and informal sectors of the economy are threatened.

- There is a need for banks to extend repayment holidays for principal amounts on loans advanced to individuals and corporate. This repayment holiday will ensure that the upliftment of the debt burden results in increased consumer disposable income. To support this initiative, the RBZ will need to come up with suitable market instruments to aid banks with liquidity to anchor such an initiative.

- There is a need for the government to pay pharmaceutical manufacturers in foreign currency in order to maintain an adequate supply of drugs in line with the increased demand of flu-related medicines. With a weaker ZW\$ most 
pharmaceutical manufacturers were opting to export their produce in order to raise foreign currency.

- There is a need for the RBZ to consider a downward review of foreign currency retention thresholds on export earnings in order to ensure the viability of the mining and tobacco subsectors of the economy. This will ensure that exporter retains a significant portion of their earnings in foreign currency and thereby cushioning them against the loss in value due the weaker Zimbabwe Dollar.

- Government should review the 2 percent intermediation money transfer tax threshold currently pegged at ZW\$100. At the current official exchange rate of ZW $\$ 25$ per US $\$ 1$, this will be only US $\$ 4$. The threshold should be reviewed upwards to at $\mathrm{ZW} \$ 1000$ in line with the current reality of the erosion of value due to a depreciating exchange rate and the inflationary pressures.

- Government should be applauded for removing custom duties on Covid-19 related drugs, materials and equipment as well as offering income tax moratoriums to health workers (ZIMCODD, 2020).

Apart from the emergency measures outlined above, it is the argument of this article that government and policy makers should equally give premium attention to the long term impact of the coronavirus on the national economy. In this respect, it is imperative for government to craft policies that will lead to greater domestic resource mobilisation. It is almost trite to state that Zimbabwe is richly endowed with natural resources including huge tracts of arable land, timber, wild life, and fisheries.

Besides, the country has the world's third largest platinum reserves and is the fifth largest producer of lithium, which is essential for rechargeable batteries (African Development Bank, 2018). The country is also rich in precious stones and other mineral resources such as gold, coal, iron ore, chromium ore, diamonds, vanadium, asbestos, nickel, and copper among others. All these should be leveraged and harnessed for the development of the country. Understandably, at the moment the depressed global demand for commodity exports may hinder the country from benefiting from its resources, however, as the world slowly reopens to business, Zimbabwe should stand ready to take advantage of the opportunities that will avail themselves in the post-Covid-19 crisis.

At the same time, Zimbabwe will need to generate more resources through innovative domestic resource instruments that are likely to crowd in more private sector investment. Mechanisms such as Public Private Partnerships (PPPs), Diaspora Remittances, Sovereign Wealth Funds (SWFs), Intermediated Money Transfer Tax, and digital tools are at the government's disposal. To further improve its domestic resource mobilisation effort in this age of digital economies, Zimbabwe should fully embrace the idea of the Fourth Industrial Revolution (4IR) with all its attendant aspects such as artificial intelligence (AI), internet of things, robotics, and cloud counting among others in order to be able to deal with financial cybercrimes and other internet based tax-avoidance and money laundering crimes. It is therefore the contention of this discussion that policy 
makers should be finely attuned to the merits of increased domestic resource mobilisation in order to raise resources to fight the impact of the pandemic in the long term.

\section{Going Forward: Strengthening Public Finance Management}

As intimated earlier, scholars and observers have pointed to high levels of government corruption and low levels of transparency and accountability as being responsible for the low levels of popular trust in the government of Zimbabwe. Given the problem of corruption and illicit financial flows in the country, there is a need for public financial management (PFM) reforms. These should aim at improving financial systems with the goal of better collecting revenues and distributing these to curb the effects of Covid-19 among the other social and economic needs.

Specifically, there is a need to examine the relations between the ministries, departments and other institutions involved in the fight against Covid-19. What is unsettling about the current funding is that there is no systematic resource or tool for tracking Covid-19 contributions, a situation made more complex by the fact that the contributions are made directly to the President of Zimbabwe. This has given rise to the claims that some of the contributions are now used by the First Lady through her Non-Governmental Organisation-the Angel of Hope which is distributing them as her personal gifts rather than a government programme that should be subjected to public accountability.

ZIMCODD (2020: p. 40) was right when it noted that even in the midst of the current crisis, it is always important to observe the principles of good public finance management to ensure effective utilisations of resources in fighting Covid-19. In particular, given the record of mismanagement of public resources in Zimbabwe, development partners, international financial institutions, philanthropists, and the citizens at large would want assurance that their contributions and grants are properly deployed to fight Covid-19. While some international agencies including the UN Humanitarian agencies may directly deploy their resources to the needy communities and cases, it is argued here that government should establish a Covid-19 National Trust Fund that will be responsible for collecting and administering all the resources mobilised to respond to the coronavirus crisis.

The Trust may be established in terms of Section 10 of the Public Finance Management Act (Chapter 22: 19) which effectively gives the Minister of Finance the power to establish such a fund (ZIMCODD, 2020). The setting up of the Trust would allow for the ring-fencing of all resources raised to combat Covid-19 pandemic and minimise the risk of funds being used for unintended purposes and being co-mingled with other fiscal expenditures that have nothing to do with the coronavirus crisis.

In this sense, the Covid-19 National Trust Fund must be independently governed through the appointment of respected members of society to take up the 
governance roles of the fund. This view is shared by a number of respected Zimbabweans including Strive Masiyiwa a respected Zimbabwean billionaire who has generously contributed to the fight against the coronavirus through his Econet Company. Apparently, this model has been adopted in Ghana where private citizens and organisations contribute towards fighting against Covid-19.

In short, transparency in public finance management is considered here as an important means of mobilisation, management, and utilisation of public resources. It is therefore important that the government of Zimbabwe establishes a system for monitoring and accounting for all the resources mobilised towards the fight against Covid-19. It is equally argued that the transparent nature of accounting for these resources would most likely result in greater participation by philanthropists, private corporations and development partners in supporting the containment of the coronavirus efforts by government (ZIMCODD, 2020).

\section{Conclusion}

This article has noted that Zimbabwe is struggling with the outbreak of the coronavirus impact on public health care, livelihoods, and the national economy. It was also observed that the country has been in the crisis mode since the beginning of the $21^{\text {st }}$ century hence the Covid- 19 crisis found the country without resources and unprepared for the pandemic. The article decoupled some of the obstacles and opportunities for financing not just the health dimensions of the crisis but also the livelihoods of millions of people that have been destroyed by the measures meant to curb the spread of the virus as well as the negative impact of the pandemic on the critical sectors of the economy. It was concluded that the country will benefit from debt cancellations, grant funding, special drawing rights, and domestic resource mobilisation coupled with effective public finance management. The confluence of these measures would together provide the much needed fiscal space to combat the coronavirus crisis without inducing further debt strain on the economy.

This research faced three major limitations namely: the conditions around Covid-19 are fast changing, by the time of going to the press perhaps some of the challenges raised here will have been solved and new ones would have emerged; it was conducted under the conditions of the lockdown hence there was no chance of physically inspecting the various health facilities; and the research paid scant attention to the domestic resource mobilisation and yet it is the most important source for government revenues. As such, future research needs to focus on how government can enhance its domestic resource mobilisation efforts especially through innovative financing mechanisms in order to have financial independence as it battles against the immediate, medium and long-term effects of the coronavirus. Be that as it may, this study is important to policy makers, health professionals, donors, civil society, and the media all of which are directly involved in the fight against the coronavirus. It identifies the challenges they need to overcome and the opportunities they need to take in order to limit the 
scourge of the pandemic in Zimbabwe.

\section{Conflicts of Interest}

The author declares no conflicts of interest regarding the publication of this paper.

\section{References}

ActionAid (2020). IMF Meetings Fail to Agree Support to Protect Developing Countries from COVID19.

https://actionaid.org/opinions/2020/imf-meetings-fail-agree-support-protect-developi ng-countries-covid19

Adhikari, P. (2020). Nepal Needs Total Debt Cancellation to Face the COVID-19 Crisis. https://www.cadtm.org/Nepal-needs-Total-Debt-Cancellation-to-face-the-COVID-19Crisis

African Development Bank (2018). Economic Report: Building a New Zimbabwe: Targeted Policies for Growth and Job Creation. Tunis: African Development Bank. https://www.afdb.org/en/documents/document/zimbabwe-economic-report-building-a -new-zimbabwe-targeted-policies-for-growth-and-job-creation-106282

Chidaushe, M. (2020). COVID-19: The Road Ahead Is Long and Bumpy-But We Will Recover and Come Out Stronger.

http://www.zela.org/covid-19-the-road-ahead-is-long-and-bumpy-but-we-will-recover -and-come-out-stronger/

Chigumira, G., Mupunga, N., \& Chipumho, E. (2018). An Assessment of Arrears Clearance and Sustainable Debt Options for Zimbabwe. Harare: ZIPARU/ACDF.

http://www.zeparu.co.zw/sites/default/files/2019-03/An\%20assesment\%20of\%20arrears \%20clearance\%20web\%20\%281\%29.pdf

Choruma, A. (2018). Corruption Stalls Zimbabwe's Economic Agenda. The Financial Gazette. http://iffoadatabase.trustafrica.org/iff/Corruption\%20stalls\%20Zimbabwe\%E2\%80\%99 s\%20economic\%20agenda\%20_\%20The\%20Financial\%20Gazette.pdf

Daily Nation News (2020). Will the Rich Agree to Debt Waiver in Face of COVID-19 Crisis?

https://www.nation.co.ke/lifestyle/smartcompany/Will-the-rich-agree-to-debt-waiver-i n-face-of-Covid-19-crisis/1226-5547706-js7nie/index.html

Dlamini, B., \& Mbira, L. (2017). The Current Zimbabwean Liquidity Crisis: A Review of Its Precipitates. Journal of Economics and Behavioral Studies, 9, 212-219.

https://www.researchgate.net/publication/318589838_The_Current_Zimbabwean_Liqu idity_Crisis_A_Review_of_its_Precipitates

Eurodad (2020). Six Things You Should Know about COVID-19 and Debt for Developing Countries. https://eurodad.org/covid19-debt-FAQ

Gallagher, K., Ocampo, J. A., \& Vulz, U. (2020). IMF Special Drawing Rights: A Key Tool for Attacking a Covid-19 Financial Fallout in Developing Countries.

https://www.brookings.edu/blog/future-development/2020/03/26/imf-special-drawingrights-a-key-tool-for-attacking-a-covid-19-financial-fallout-in-developing-countries/

Global Justice (2020) Coronavirus: IMF Told to Massively Scale Up Debt Cancellation for Developing World.

https://www.globaljustice.org.uk/news/2020/apr/14/coronavirus-imf-told-massively-sc ale-debt-cancellation-developing-world

Government of Zimbabwe (2019). The 2020 Budget Speech by the Minister of Finance. 
Harare: Parliament of Zimbabwe. http://www.veritaszim.net/node/3791

IMF (2020). Policy Responses to COVID-19.

https://www.imf.org/en/Topics/imf-and-covid19/Policy-Responses-to-COVID-19

Jubilee Debt Campaign (2015). The New Debt Trap: How the Response to the Last Global Financial Crisis Has Laid the Ground for the Next. London: Jubilee Debt Campaign. https://jubileedebt.org.uk/wp-content/uploads/2015/07/The-new-debt-trap_07.15.pdf

Jubilee Debt Campaign (2020). Reaction to US \$215 Million Debt Cancellation by IMF. https://jubileedebt.org.uk/press-release/reaction-to-215-million-of-debt-cancellation-b y-imf

Mckensey \& Co. (2020). Tackling COVID-19 in Africa.

https://www.mckinsey.com/featured-insights/middle-east-and-africa/tackling-covid-19 -in-africa

Moyo, D. (2009). Dead Aid: Why Aid Is Not Working and How There Is a Better Way for Africa. New York: Farrar, Straus \& Giroux.

Moyo, G. (2020). Financing Woes for Zimbabwe as It Tackles the Spectre of Covid-19. https://cemiunicamp.com.br

Ncube, M. (2020). Letter to Addressed to the Managing Director Kristalina Georgieva. IMF.

https://news.pindula.co.zw/2020/05/01/full-text-zim-finance-ministers-request-letter-f or-financial-assistance-to-imf/

New Zimbabwe Newspaper (2020). Mnangagwa’s \$18 Billion COVID-19 Package Fictitious-Biti. https://allafrica.com/stories/202005050158.html

Onyekwena, C., \& Ekeruche, A. (2020). The Case for Debt Relief in Africa amid COVID-19. https://www.africaportal.org/features/case-debt-relief-africa-amid-covid-19/

Patnaik, P. (2020). The Exodus of Finance from the Third World. https://www.im4change.org/latest-news-updates/the-exodus-of-finance-from-the-third -world.html

Reuters (2020). Zimbabwe Gets \$ 7 m COVID-19 Lifeline from World Bank. https://www.cnbcafrica.com/news/2020/05/06/zimbabwe-gets-7m-covid-19-lifeline-fro $\underline{\text { m-world-bank/ }}$

Siwisa, S. (2020). The Impact of Coronavirus on Sub-Saharan Africa. https://oecd-development-matters.org/2020/04/22/the-impact-of-coronavirus-on-sub-s aharan-africa/

Soren, A. (2005). Social Movements and the Politics of Debt Cancellation. Chicago Journal of International Law, 6, 264-285.

https://chicagounbound.uchicago.edu/cgi/viewcontent.cgi? article $=1281 \&$ context $=$ cjil

Sun, Y. (2020). China and Africa's Debt: Yes to Relief, No to Blanket Forgiveness. Africa in Focus.

https://www.brookings.edu/blog/africa-in-focus/2020/04/20/china-and-africas-debt-ye s-to-relief-no-to-blanket-forgiveness/

Telesur (2020). China Pumps \$2.5 Billion Into Zimbabwe. http://www.telesyrenglish.net

The Chronicle News Paper (2020). Government Update on COVID-19, Zimbabwe. https://www.chronicle.co.zw/

Toussaint, E. (2020). COVID-19 on Debt Assault. https://www.cadtm.org/Covid-19-on-a-debt-assault

World Bank (2020). Zimbabwe-Joint World Bank-Bank Debt Sustainability Analysis. Washington DC: World Bank Group.

http://documents.worldbank.org/curated/en/643231584980476945/Zimbabwe-Joint-W 
orld-Bank-IMF-Debt-Sustainability-Analysis

ZIMCODD (2020). Zimbabwe COVID-19 Response Mechanism: The Resource Factor. http://zimcodd.org/wp-content/uploads/2020/04/COVID-19-Response-Mechanism.pdf 